\title{
Pengaruh Perbandingan Tepung Kacang Merah (Phaseolus vulgaris. L) dan Tepung Daun Pegagan(Centella asiatica (L.) Urban) Terhadap Karakteristik Cookies
}

\author{
The Effect of Comparison Red Bean Flour (Phaseolus vulgaris L.) and \\ Centella (Centella asiatica (L.) Urban) Leaf Flour on The Characteristics of Cookies
}

\author{
Bobby Frans Siahaan ${ }^{1}$, Ni Made Yusa ${ }^{1^{*}}$, I Desak Putu Kartika Pratiwi ${ }^{1}$ \\ Program Studi Teknologi Pangan, Fakultas Teknologi Pertanian, Universitas Udayana \\ Kampus Bukit Jimbaran, Badung-Bali \\ *Penulis korespondensi: Ni Made Yusa, Email: madeyusa@unud.ac.id
}

\begin{abstract}
This research was aimed for determine the effect of comparison red bean flour and Centella leaf flour on the characteristics of cookies produced and the comparison red bean flour and Centella leaf that is able to produced cookies with the best characteristics. The research based on a Completely randomized design (CRD) with treatment the ratio of red bean flour and Centella leaf flour consisting of 5 levels: 97\%: 3\%; 94\%: 6\%; 91\%: 9\%; 88\%: 12\%; 85\%: 15\%. Each treatment was replicated 3 times to obtain 15 experimental units. Data was analyzed using analysis of variance and if the treatment had a significant effect, its followed by the Duncan multiple range test (DMRT). The results showed that the comparison of red bean flour and Centella leaf flour has a significant effect to crude fiber content, protein content, and antioxidant capacity, colour, texture, taste and overall acceptance (hedonic), colour, texture and taste (skoring). Ratio of 91\% red bean flour and 9\% Centella leaf flour for producing cookies the best characteristics with a moisture content $4.28 \%$, crude fiber content $19.87 \%$, protein content $9.33 \%$ and antioxidant capacity $85.60 \%$, color is greenish brown and liked, texture is crunchy and liked, taste is somewhat distinctive of Centella leaf and very liked, aroma and overall acceptance were liked.
\end{abstract}

Keywords: cookies, red bean flour, centella leafflour

\section{PENDAHULUAN}

Cookies adalah salah satu jenis biskuit yang dibuat dari adonan lunak, berkadar lemak tinggi, relatif renyah bila dipatahkan dan penampang potongannya bertekstur padat (Anon., 2011). Cookies adalah jenis kue kering dengan rasa manis atau gurih, bertekstur renyah, bentuknya kecil, serta terbuat dari bahan dasar tepung, lemak dan telur (Hastuti, 2012). Cookies disebut juga sebagai jenis camilan atau makanan ringan yang banyak disukai oleh sebagian besar masyarakat mulai balita sampai dewasa. Menurut Suarni (2009), konsumsi rata-rata kue kering (cookies) di kota besar dan pedesaan di Indonesia adalah $0,40 \mathrm{~kg} / \mathrm{kapita} / \mathrm{tahun}$.
Bahan baku pembuatan cookies secara umum adalah terigu dimana Indonesia masih mengimpor gandum yang merupakan bahan dasar terigu dari luar negeri, hal ini berdampak pada meningkatnya impor terigu. Kebutuhan terigu di Indonesia dari tahun ke tahun semakin meningkat (Ratih, 2011). Menurut data Badan Pusat Statistika (BPS), impor terigu pada periode Januari - Juni 2019 telah mencapai 36. 467 juta ton, mengalami kenaikan dibandingkan dengan periode yang sama pada tahun 2018 yakni 31. 905 ton (BPS 2019). Terigu mengandung protein berupa gluten yang tidak semua orang dapat mengkonsumsi dan mencerna gluten dengan baik seperti penyandang celiac disease atau gangguan saluran 
pencernaan (Yustisia, 2013). Perlu adanya upaya untuk mengurangi ketergantungan dalam impor terigu dan menggunakan bahan baku lokal alternatif yang mampu menggantikan terigu. Salah satu bahan baku lokal alternatif yang tidak mengandung gluten yaitu kacang merah. Penggunaan kacang merah juga dapat meningkatkan keanekaragaman pangan dengan cara mengoptimalkan potensi bahan baku lokal sebagai pengganti terigu.

Kacang merah (Phaseolus vulgaris L.) merupakan salah satu bahan pangan lokal di Indonesia yang memiliki protein nabati yang tinggi (Astawan 2009). Komposisi zat gizi tepung kacang merah dalam $100 \mathrm{~g}$ yaitu protein 17,24 g; lemak 2,21 g, dan karbohidrat 71,08 g (Ekawati, 1999). Keunggulan dari kacang merah adalah kaya akan protein dan bebas kolesterol. Produksi kacang merah di Indonesia juga cukup banyak, hal tersebut sesuai dengan data Badan Pusat Statistik (2019) yang menyatakan produksi kacang merah di Indonesia pada tahun 2019 mencapai 61. 520 ton. Pengolahan kacang merah menjadi tepung dapat memperpanjang umur simpannya dan dapat meningkatkan nilai ekonomisnya. Penelitian tentang tepung kacang merah telah diaplikasikan. Berdasarkan penelitian Nurul et al., (2015) tepung kacang merah dapat dimanfaatkan menjadi cookies dan menghasilkan karakteristik fisik, kimia dan uji sensoris terbaik dengan perbandingan tepung kacang merah dan terigu sebanyak 50\% : 50\%. Cookies merupakan salah satu produk bakery yang tidak membutuhkan pengembangan (unleavened product), tetapi mengutamakan pada teksturnya yang renyah. Untuk memperbaiki tekstur dari cookies yang terbuat dari tepung kacang merah, dapat ditambahkan produk alternatif yang memiliki kandungan pati yang tinggi. Salah satu produk alternatif yang dapat digunakan adalah mocaf.

Mocaf adalah produk tepung dari singkong (Manihot esculenta Crantz) yang diproses menggunakan prinsip memodifikasi struktur sel singkong secara fermentasi, dimana Bakteri Asam Laktat (BAL) mendominasi selama fermentasi tepung singkong ini (Subagio, 2012). Mocaf memiliki kandungan gizi seperti pati sebesar $85,60 \%$, protein $1,93 \%$, lemak $2,72 \%$, abu $0,30 \%$, air 9,25\%, serat $0,21 \%$ (Hidayat et al., 2009). Mocaf memiliki kandungan amilosa 19\% dan amilopektin sebesar 81\% (Wanita, 2013). Menurut Arief et al., (2012) mocaf mempunyai peran yang penting untuk meningkatkan tekstur pada produk makanan karena memiliki kandungan amilopektin yang dapat memberi efek lunak bagi adonan sehingga cookies yang dihasilkan akan lebih renyah. Cookies yang beredar di masyarakat masih memiliki kekurangan baik dari segi antioksidan, serat, serta vitamin. Untuk memperkaya nilai fungsional dari cookies, dapat ditambahkan bahan lain yang memiliki kandungan senyawa bioaktif seperti antioksidan, serat, kalsium dan pro vitamin A (Fatmawati, 2012).

Sumber antioksidan, vitamin dan serat dapat diperoleh dari sayur-sayuran. Daun pegagan (Centella asiatica (L.) Urban) merupakan salah satu sayuran yang mengandung vitamin, mineral dan antioksidan yang tinggi dengan IC50 4,0 mg/ml dan $7,0 \mathrm{mg} / \mathrm{ml}$ yang berguna untuk menjaga kesehatan tubuh (Sutardi, 2016 dalam Ullah et al., 2007). Keunggulan pegagan yaitu memiliki efek farmakologis antara lain sebagai anti inflamasi, memperbaiki sistem syaraf pusat, obat lepra, TBC 
dan antiulcer (Arora et al., 2002). Pemanfaatan daun pegagan untuk olahan produk pangan masih sedikit ditemukan. Khusus di Bali, daun pegagan hanya dimanfaatkan sebagai minuman herbal atau disebut sebagai loloh don piduh yang dipercaya dapat meningkatkan nafsu makan (Putra et al., 2019). Daun pegagan mengandung total klorofil sebesar $831,5 \mathrm{mg} / \mathrm{kg}$ (Nurdin et al., 2009). Hasil penelitian Siregar et al., (2017) tentang analisis kandungan serat kasar pada daun pegagan sebesar 5,46\% dan hasil penelitian Mustikarini (2015) tentang analisis kandungan vitamin $\mathrm{C}$ pada daun pegagan sebesar $0,98 \mathrm{mg} / \mathrm{g}$. Menurut Ariyasa et al., (2018) pegagan dapat dimanfaatkan sebagai cookies dengan perbandingan $89 \%$ tepung kimpul dengan $11 \%$ pasta daun pegagan menghasilkan cookies dengan karakteristik terbaik yaitu: kadar air 4,41\%, kadar serat kasar 7,21\%, total klorofil 2,51 mg/kg, kadar vitamin C $1,54 \mathrm{mg} / \mathrm{g}$, aktivitas antioksidan (berdasarkan nilai $\mathrm{IC}_{50}$ ) 65,61\%.

Berdasarkan uraian diatas maka dilakukan penelitian perbandingan tepung kacang merah dan tepung daun pegagan dengan tujuan mengetahui pengaruh perbandingan tepung kacang merah dan tepung daun pegagan terhadap karakteristik cookies dan mengetahui perbandingan tepung kacang merah dan tepung daun pegagan yang tepat sehingga menghasilkan cookies dengan karakteristik terbaik. Penelitian ini diharapkan dapat meningkatkan kandungan nilai gizi cookies dan menjadikan cookies sebagai alternatif pangan fungsional serta dapat melakukan diversikasi pangan dengan menggunakan kacang merah sebagai bahan dasar pembuatan cookies yang bisa dikonsumsi oleh berbagai kalangan termasuk penyandang celiac disease.

\section{METODE PENELITIAN}

\section{Tempat dan Waktu Penelitian}

Penelitian ini dilaksanakan di Laboratorium Analisis Pangan, Laboratorium Pengolahan Pangan, dan Laboratorium Biokimia dan Nutrisi, Fakultas Teknologi Pertanian, Universitas Udayana. Penelitian ini dilaksanakan pada bulan Agustus 2020 sampai dengan bulan September 2020.

\section{Bahan dan Alat}

Bahan-bahan yang digunakan dalam penelitian ini terdiri dari bahan baku, bahan tambahan, dan bahan kimia. Bahan baku terdiri tepung kacang merah yang diperoleh dari toko Irdina Cahyani, Yogyakarta dan daun pegagan segar yang masih hijau, tidak keriput, dan tidak dimakan ulat yang berasal dari Kabupaten Gianyar yang didistribusikan di Tiara Dewata, Denpasar. Bahan tambahan terdiri dari mocaf, margarin merk blueband, gula halus, kuning telur dan baking powder yang diperoleh dari toko Fenny, Denpasar. Bahan kimia yang digunakan dalam melakukan analisis meliputi $\mathrm{H}_{2} \mathrm{SO}_{4}, \mathrm{NaOH}$, powder Kjeldahl, alkohol 96\%, aquadest, indikator pp (phenolphthalein), hexane, methanol, 1,1-difenil-2pikrilhidrazil (DPPH), dan asam galat yang diperoleh dari CV. Chem-Mix Pratama, Yogyakarta.

Alat yang digunakan dalam pembuatan cookies adalah mixer (elektrolux), pisau, talenan, sutil, sendok, gunting, waskom, panci, blender (Philips), rolling pan, timbangan digital (ACIS), kompor gas (Rinnai), oven kue (Kirin), cetakan cookies dan loyang. Alat yang digunakan untuk analisis sifat fisik dan kimia adalah lumpang, kertas 
saring, kertas Whatman 42, corong plastik, desikator, botol timbang, oven (Memmert), timbangan analitik (Shimadzu), aluminium foil (Klin Pak), pinset, pipet tetes, pipet volume (Pyrex), batang pengaduk, vortex (Maxi mix II), kompor listrik, labu erlenmeyer (Pyrex), gelas beaker (Pyrex), gelas ukur (Pyrex), pompa karet, labu takar (Pyrex), tabung reaksi (Pyrex), waterbath (thermology), spektrofotometer (Libra), perangkat komputer dan lembar quisioner.

\section{Rancangan Penelitian}

Penelitian ini menggunakan Rancangan Acak Lengkap (RAL) dengan perlakuan perbandingan tepung kacang merah dan tepung daun pegagan yang terdiri dari 5 taraf meliputi P1 $=97 \%: 3 \%, \mathrm{P} 2=94 \%: 6 \%, \mathrm{P} 3=91 \%: 9 \%, \mathrm{P} 4=$ $88 \%$ : $12 \%$, P5 $=85 \%$ : 15\%. Masing-masing perlakuan diulang sebanyak 3 kali sehingga diperoleh 15 unit percobaan. Data yang diperoleh dianalisis menggunakan sidik ragam atau Analysis of Variance (ANOVA). Apabila dari hasil uji tersebut berpengaruh nyata maka dilanjutkan dengan uji Duncan's Multiple Range Test (DMRT) menggunakan Statistical Product and Service Solution (SPSS) Statistics 25 dengan selang kepercayaan 95\% (Gomez dan Gomez, 1995).

\section{Pelaksanaan Penelitian}

Tahap pelaksanaan penelitian meliputi dua proses yaitu proses pembuatan tepung daun pegagan dan proses pembuatan cookies.

\section{Proses Pembuatan Tepung Daun Pegagan}

Proses pembuatan tepung daun ini menggunakan metode yang dilaporkan Intartia
(2017) yang dimodifikasi. Daun pegagan segar dipisahkan dari tangkainya, dicuci dengan air mengalir hingga bersih. Daun pegagan yang sudah dicuci diletakkan pada loyang lalu ditaruh diatas rak oven dan diatur ketebalannya sedemikian rupa, selanjutnya dikeringkan menggunakan oven dengan suhu $40^{\circ} \mathrm{C}$ selama 5 jam. Daun pegagan kering diblender sampai halus dan diayak menggunakan ayakan 80 mesh.

\section{Proses Pembuatan Cookies}

Proses pembuatan cookies ini menggunakan metode yang dilaporkan Marissa (2010) yang dimodifikasi. Tahap pembuatan cookies diawali dengan gula halus dan margarin dicampur menggunakan mixer selama 2 menit selanjutnya dimasukkan kuning telur dan dicampur menggunakan mixer selama 2 menit, setelah itu dimasukan tepung kacang merah, tepung daun pegagan dan mocaf sesuai perlakuan, serta baking powder kemudian dicampur menggunakan mixer selama 2 menit hingga membentuk adonan cookies. Adonan cookies digiling menggunakan roolpan, ditimbang masing-masing $\pm 5 \mathrm{~g}$ dan dicetak menggunakan cetakan cookies. Adonan yang telah dicetak diletakan pada loyang yang telah diolesi margarin setelah itu adonan dipanggang didalam oven dengan suhu $150^{\circ} \mathrm{C}$ selama 15-20 menit, maka dihasilkan cookies.

\section{Komposisi bahan pembuatan cookies} dengan perbandingan tepung kacang merah dan tepung daun pegagan dapat dilihat pada Tabel 1. 
Tabel 1. Komposisi bahan pembuatan cookies dengan perbandingan tepung kacang merah dan tepung daun pegagan

\begin{tabular}{cccccc}
\hline \multirow{2}{*}{ Komposisi bahan } & P1 & P2 & P3 & P4 & P5 \\
\cline { 2 - 6 } & 97 & 94 & 91 & 88 & 85 \\
\hline Tepung kacang merah (\%) & 3 & 6 & 9 & 12 & 15 \\
Tepung daun pegagan (\%) & 20 & 20 & 20 & 20 & 20 \\
Mocaf (\%) & 60 & 60 & 60 & 60 & 60 \\
Margarin (\%) & 60 & 60 & 60 & 60 & 60 \\
Gula halus (\%) & 20 & 20 & 20 & 20 \\
Kuning telur (\%) & 1 & 1 & 1 & 1 \\
Baking powder (\%) & 1 & (\%)
\end{tabular}

Keterangan: Persentase bahan-bahan diatas berdasarkan jumlah tepung kacang merah dan tepung daun pegagan $(100 \mathrm{~g})$

Sumber : Ariyasa et al., (2018) yang dimodifikasi

\section{Variabel yang diamati}

Variabel yang diamati dalam penelitian ini adalah kadar air diukur dengan metode pengeringan (Andarwulan et al., 2011), kadar serat kasar diukur dengan metode hidrolisis asam dan basa (Andarwulan et al., 2011), kadar protein diukur dengan metode Mikro-kjeldahl (Andarwulan et al., 2011), kapasitas antioksidan diukur dengan metode DPPH (Blois, 1958 dalam Hanani et al., 2005), dan evaluasi sensoris meliputi warna, aroma, tekstur, rasa dan penerimaan keseluruhan (hedonik) serta warna, tekstur dan rasa (skoring) (Soekarto, 1985).

\section{HASIL DAN PEMBAHASAN}

\section{Hasil Analisis Bahan Baku}

Nilai rata-rata hasil analisis kadar air, kadar serat kasar, kadar protein dan kapasitas antioksidan tepung kacang merah dan tepung daun pegagan dapat dilihat pada Tabel 2.

Tabel 2. Nilai rata-rata kadar air, kadar serat kasar, kadar protein, kapasitas antioksidan dari tepung kacang merah dan tepung daun pegagan

\begin{tabular}{lcc}
\hline \multicolumn{1}{c}{ Komponen } & Tepung Kacang Merah & Tepung Daun Pegagan \\
\hline Kadar Air (\%) & 15,56 & 37,53 \\
Kadar Serat Kasar (\%) & 21,82 & 8,43 \\
Kadar Protein (\%) & 21,61 & 17,19 \\
Kapasitas Antioksidan (\%) & 56,21 & 91,34 \\
\hline
\end{tabular}

\section{Hasil Analisis Kimia Cookies}

Nilai rata-rata hasil analisis kadar air, kadar serat kasar, kadar protein dan kapasitas antioksidan pada cookies dapat dilihat pada Tabel 3.

\section{Kadar Air}

Hasil sidik ragam menunjukkan bahwa perbandingan tepung kacang merah dan tepung daun pegagan berpengaruh tidak nyata $(\mathrm{P}>0,05)$ terhadap kadar air dari cookies. Berdasarkan analisis bahan baku, kadar air tepung kacang merah sebesar $15,56 \%$ dan kadar air tepung daun pegagan sebesar 37,53\% (Tabel 2). Mengacu pada syarat mutu cookies (SNI No. 2973-2011), kadar air pada cookies adalah maksimal \% bb sehingga kadar air 
cookies pada semua perlakuan telah memenuhi SNI

No. 2973-2011.

Tabel 3. Nilai rata-rata kadar air, kadar serat kasar, kadar protein dan kapasitas antioksidan cookies.

\begin{tabular}{ccccc}
\hline $\begin{array}{c}\text { Perlakuan } \\
(\text { TKM : TDP) }\end{array}$ & $\begin{array}{c}\text { Kadar Air } \\
\mathbf{( \% )}\end{array}$ & $\begin{array}{c}\text { Kadar } \\
\text { Serat Kasar } \\
(\%)\end{array}$ & $\begin{array}{c}\text { Kadar Protein } \\
(\%)\end{array}$ & $\begin{array}{c}\text { Kapasitas } \\
\text { Antioksidan (\%) }\end{array}$ \\
\hline P1 $(97 \%: 3 \%)$ & $3,86 \pm 1,23^{\mathrm{a}}$ & $16,72 \pm 0,48^{\mathrm{a}}$ & $8,24 \pm 0,41^{\mathrm{a}}$ & $48,17 \pm 1,79^{\mathrm{a}}$ \\
P2 $(94 \%: 6 \%)$ & $4,21 \pm 1,90^{\mathrm{a}}$ & $18,25 \pm 0,60^{\mathrm{ab}}$ & $8,65 \pm 0,51^{\mathrm{a}}$ & $63,50 \pm 5,67^{\mathrm{b}}$ \\
P3 $(91 \%: 9 \%)$ & $4,28 \pm 1,78^{\mathrm{a}}$ & $19,87 \pm 0,44^{\mathrm{b}}$ & $9,33 \pm 0,27^{\mathrm{ab}}$ & $85,60 \pm 3,21^{\mathrm{c}}$ \\
P4 $(88 \%: 12 \%)$ & $4,55 \pm 1,27^{\mathrm{a}}$ & $22,86 \pm 1,67^{\mathrm{c}}$ & $10,28 \pm 0,83^{\mathrm{bc}}$ & $86,38 \pm 1,71^{\mathrm{c}}$ \\
P5 $(85 \%: 15 \%)$ & $4,60 \pm 0,92^{\mathrm{a}}$ & $24,05 \pm 0,87^{\mathrm{c}}$ & $10,96 \pm 1,07^{\mathrm{c}}$ & $87,04 \pm 0,89^{\mathrm{c}}$ \\
\hline
\end{tabular}

Keterangan: Nilai rata-rata yang diikuti oleh huruf yang sama pada kolom yang sama menunjukkan berpengaruh tidak nyata $(\mathrm{P}>0,05)$

TKM $=$ Tepung Kacang Merah

TDP $=$ Tepung Daun Pegagan

\section{Kadar Serat Kasar}

Hasil sidik ragam menunjukan bahwa perbandingan tepung kacang merah dan tepung daun pegagan berpengaruh nyata $(\mathrm{P}<0,05)$ terhadap kadar serat kasar cookies. Hasil penelitian menunjukkan nilai rata-rata kadar serat kasar cookies pada semua taraf perlakuan yang dihasilkan berada pada rentang 16,72\%-24,05\% (Tabel 2). Nilai rata-rata kadar serat kasar cookies tertinggi diperoleh dari cookies pada perlakuan P5 ( $85 \%$ tepung kacang merah dan $15 \%$ tepung daun pegagan) yaitu sebesar $24,05 \%$ dan tidak berbeda dengan perlakuan $\mathrm{P} 4$, sedangkan nilai rata-rata kadar serat kasar cookies terendah diperoleh dari cookies pada perlakuan P1 (97 \% tepung kacang merah dan 3\% tepung daun pegagan) yaitu $16,72 \%$ dan tidak berbeda dengan perlakuan P2 (Tabel 3).

Peningkatan penambahan tepung daun pegagan dalam pembuatan cookies mengakibatkan kadar serat kasar dari cookies semakin tinggi. Hal ini dikarenakan tepung daun pegagan juga merupakan penyumbang serat dari bahan pembuatan cookies lainnya. Hasil ini sesuai dengan penelitian Intartia (2016) mengenai pengaruh penambahan serbuk pegagan pada crackers yang menyatakan bahwa jumlah serbuk pegagan yang ditambahkan berpengaruh sangat nyata terhadap kadar serat kasar crackers, dengan kadar serat kasar tertinggi diperoleh pada P3 (penambahan serbuk pegagan $10 \%$ ) yaitu 1,69\% sedangkan serat kasar terendah diperoleh pada P1 (penambahan serbuk pegagan $5 \%$ ) yaitu $1,07 \%$. Berdasarkan analisis bahan baku, kadar serat kasar tepung daun pegagan adalah $8,43 \%$, sedangkan kadar serat pada tepung kacang merah adalah 21,82\% (Tabel 2). Mengacu pada syarat mutu cookies (SNI No. 29732011), kadar serat kasar cookies adalah maksimum 0,5\% sehingga untuk kadar serat semua perlakuan tidak sesuai dengan standar SNI yaitu lebih dari batas maksimum serat kasar yang telah ditetapkan oleh SNI.

\section{Kadar Protein}

Hasil sidik ragam menunjukkan bahwa perbandingan tepung kacang merah dan tepung 
daun pegagan berpengaruh nyata $(\mathrm{P}<0,05)$ terhadap kadar protein dari cookies. Hasil penelitian menunjukkan nilai rata-rata kadar protein cookies pada semua taraf perlakuan berada pada rentang 8,24\%-10,96\% (Tabel 3). Nilai ratarata kadar protein cookies tertinggi diperoleh dari cookies pada perlakuan P5 (85\% tepung kacang merah dan $15 \%$ daun pegagan) yaitu sebesar 10,96\% dan tidak berbeda dengan perlakuan P4, sedangkan nilai rata-rata kadar protein cookies terendah diperoleh dari cookies pada perlakuan P1 (97\% tepung kacang merah dan 3\% tepung daun pegagan) yaitu $8,24 \%$ dan tidak berbeda dengan $\mathrm{P} 2$ (Tabel 3).

Kadar protein cookies mengalami peningkatan seiring dengan peningkatan penggunaan tepung daun pegagan. Hal ini dikarenakan tepung daun pegagan merupakan penyumbang protein dari bahan pembuatan cookies lainnya. Berdasarkan analisis bahan baku, kadar protein pada tepung daun pegagan sebesar $17,19 \%$, sedangkan kadar protein pada tepung kacang merah sebesar 21,61\% (Tabel 2). Mengacu pada syarat mutu cookies (SNI No. 2973-2011), kadar protein cookies adalah maksimum 5\% sehingga kadar protein pada semua perlakuan sudah sesuai dengan standar SNI.

\section{Kapasitas Antioksidan}

Hasil sidik ragam menunjukkan bahwa perbandingan tepung kacang merah dan tepung daun pegagan berpengaruh nyata $(\mathrm{P}<0,05)$ terhadap kapasitas antioksidan cookies. Hasil penelitian menunjukkan nilai rata-rata kapasitas antioksidan cookies pada semua taraf perlakuan berada pada rentang 48,17\%-87,04\% (Tabel 3).
Nilai rata-rata kapasitas antioksidan tertinggi diperoleh dari cookies pada perlakuan P5 (85\% tepung kacang merah dan $15 \%$ tepung daun pegagan) yaitu $87,04 \%$ dan tidak berbeda dengan perlakuan P3 dan P4. Nilai rata-rata kapasitas antioksidan terendah diperoleh dari cookies pada perlakuan P1 (97\% tepung kacang merah dan 3\% tepung daun pegagan) yaitu 48,17\% (Tabel 3). Kapasitas antioksidan pada cookies signifikan meningkat sampai dengan perlakuan P3 namun setelah itu tidak mengalami peningkatan yang signifikan pada perlakuan P4 dan P5. Semakin tinggi konsentrasi penggunaan tepung daun pegagan menyebabkan kapasitas antioksidan pada cookies meningkat. Hasil analisis bahan baku, tepung daun pegagan mengandung kapasitas antioksidan sebesar 91,34\%, sedangkan tepung kacang merah mengandung kapasitas antioksidan sebesar 56,21\% (Tabel 2).

Tepung daun pegagan merupakan salah satu bahan baku yang memiliki kapasitas antioksidan yang tinggi. Senyawa antioksidan alami yang banyak terdapat dalam sayuran atau dedaunan hijau adalah klorofil. Menurut Marquez et al., (2005), klorofil dan turunannya memiliki kemampuan sebagai antioksidan. Daun pegagan memiliki kadar total klorofil sebesar $831,5 \mathrm{mg} / \mathrm{kg}$ (Nurdin et al., 2009). Kandungan klorofil tertinggi pada pegagan adalah pada bagian daun. Menurut Chandrika (2015) tanaman pegagan juga memiliki senyawa lain yang berpotensi sebagai antioksidan yakni polifenol, flavonoid, carotene, tanin, vitamin C, dan triterpenoid (asiaticoside). 


\section{Evaluasi Sensoris Cookies}

Nilai rata-rata hedonik terhadap warna, aroma, tekstur, rasa dan penerimaan keseluruhan cookies dapat dilihat pada Tabel 4 dan nilai ratarata skoring terhadap warna, tekstur dan rasa cookies dapat dilihat pada Tabel 5.

Tabel 4. Nilai rata-rata hedonik terhadap warna, aroma, tekstur, rasa dan penerimaan cookies

\begin{tabular}{cccccc}
\hline Perlakuan & Warna & Aroma & Tekstur & Rasa & $\begin{array}{c}\text { Penerimaan } \\
\text { Keseluruhan }\end{array}$ \\
\hline P1 $(97 \%: 3 \%)$ & $4,25 \pm 0,78^{\mathrm{c}}$ & $4,50 \pm 0,60^{\mathrm{a}}$ & $4,40 \pm 0,82^{\mathrm{a}}$ & $4,20 \pm 0,76^{\mathrm{b}}$ & $4,50 \pm 0,60^{\mathrm{b}}$ \\
P2 $(94 \%: 6 \%)$ & $4,50 \pm 0,60^{\mathrm{c}}$ & $4,30 \pm 0,73^{\mathrm{a}}$ & $4,50 \pm 0,60^{\mathrm{a}}$ & $4,25 \pm 0,71^{\mathrm{b}}$ & $4,45 \pm 0,60^{\mathrm{b}}$ \\
P3 (91\%:9\%) & $4,15 \pm 0,74^{\mathrm{c}}$ & $4,25 \pm 0,71^{\mathrm{a}}$ & $4,25 \pm 0,63^{\mathrm{a}}$ & $4,50 \pm 0,51^{\mathrm{b}}$ & $4,10 \pm 0,79^{\mathrm{ab}}$ \\
P4 (88\%: 12\%) & $3,60 \pm 0,79^{\mathrm{b}}$ & $3,90 \pm 0,74^{\mathrm{a}}$ & $4,05 \pm 0,87^{\mathrm{a}}$ & $3,45 \pm 0,88^{\mathrm{a}}$ & $3,80 \pm 0,76^{\mathrm{a}}$ \\
P5 (85\%:15\%) & $3,00 \pm 0,90^{\mathrm{a}}$ & $4,15 \pm 0,74^{\mathrm{a}}$ & $4,35 \pm 0,7^{8 \mathrm{a}}$ & $3,45 \pm 0,87^{\mathrm{a}}$ & $3,80 \pm 0,69^{\mathrm{a}}$ \\
\hline
\end{tabular}

Keterangan: Nilai rata-rata yang diikuti oleh huruf yang sama pada kolom yang sama menunjukkan berpengaruh tidak nyata $(\mathrm{P}>0,05)$

TKM $=$ Tepung Kacang Merah TDP $=$ Tepung Daun Pegagan

Kriteria hedonik: 1 (sangat tidak suka), 2 (tidak suka), 3 (biasa), 4 (suka), 5 (sangat suka)

Tabel 5. Nilai rata-rata skoring terhadap warna, tekstur dan rasa cookies

\begin{tabular}{cccc}
\hline Perlakuan (TKM : TDP) & Warna & Tekstur & Rasa \\
\hline P1 $(97 \%: 3 \%)$ & $2,30 \pm 0,57^{\mathrm{a}}$ & $4,10 \pm 0,78^{\mathrm{bc}}$ & $4,25 \pm 0,55^{\mathrm{d}}$ \\
P2 $(95 \%: 6 \%)$ & $3,05 \pm 0,82^{\mathrm{b}}$ & $4,50 \pm 0,51^{\mathrm{c}}$ & $3,05 \pm 0,82^{\mathrm{c}}$ \\
P3 $(92 \%: 9 \%)$ & $3,90 \pm 0,44^{\mathrm{c}}$ & $3,85 \pm 0,93^{\mathrm{ab}}$ & $2,60 \pm 0,23^{\mathrm{bc}}$ \\
P4 $(88 \%: 12 \%)$ & $4,45 \pm 0,88^{\mathrm{d}}$ & $3,55 \pm 0,94^{\mathrm{a}}$ & $2,25 \pm 0,14^{\mathrm{b}}$ \\
P5 (85\%:15\%) & $4,95 \pm 0,22^{\mathrm{e}}$ & $3,80 \pm 0,69^{\mathrm{ab}}$ & $1,60 \pm 0,75^{\mathrm{a}}$ \\
\hline
\end{tabular}

Keterangan : Nilai rata-rata yang diikuti oleh huruf yang sama pada kolom yang sama menunjukkan berpengaruh tidak nyata $(\mathrm{P}>0,05)$

TKM $=$ Tepung Kacang Merah

TDP $=$ Tepung Daun Pegagan

Kritera skoring warna : 1) coklat muda, 2) coklat kekuningan, 3) coklat kehijauan, 4) hijau muda, 5) hijau tua Krteria skoring tekstur : 1) tidak renyah, 2) kurang renyah, 3) agak renyah, 4) renyah, 5) sangat renyah Kiteria skoring rasa : 1) sangat khas daun pegagan, 2) khas daun pegagan, 3) agak khas daun pegagan,

4) khas kacang merah, 5) sangat khas kacang merah

\section{Warna}

Hasil sidik ragam menunjukkan bahwa perbandingan tepung kacang merah dan tepung daun pegagan berpengaruh nyata $(\mathrm{P}<0.05)$ terhadap warna (hedonik) cookies. Tabel 4 menunjukkan bahwa nilai rata-rata skor tertinggi terhadap warna (hedonik) cookies terdapat pada perlakuan P2 (95\% tepung kacang merah dan 5\% tepung daun pegagan) yaitu 4,50 (sangat suka), sedangkan nilai rata-rata skor terendah terhadap warna (hedonik) cookies terdapat pada perlakuan P5 (88\% tepung kacang merah dan 12\% tepung daun pegagan) yaitu 3,00 (biasa). Kesukaan panelis terhadap warna cookies dipengaruhi oleh warna alami pada bahan baku, baik yang berasal dari 
kacang merah maupun dari daun pegagan itu sendiri.

Hasil sidik ragam menunjukkan bahwa perbandingan tepung kacang merah dan tepung daun pegagan berpengaruh nyata $(\mathrm{P}<0.05)$ terhadap warna (skoring) cookies. Tabel 5 menunjukkan bahwa bahwa nilai rata-rata skor tertinggi terhadap warna (skoring) terdapat pada perlakuan P5 (85\% tepung kacang merah dan 15\% tepung daun pegagan) yaitu 4,95 (hijau tua). Penambahan tepung daun pegagan mempengaruhi tingkat kehijaun pada cookies, semakin banyak penambahan tepung daun pegagan maka tingkat kehijauan cookies semakin bertambah. Hal tersebut dikarenakan pada daun pegagan mengandung senyawa klorofil yang memberikan warna hijau. Menurut Setiari et al., (2009) daun pegagan mengandung total klorofil sebesar 24,29 $\mathrm{mg} / \mathrm{kg}$. Nilai rata-rata skor terendah terhadap warna (skoring) terdapat pada perlakuan P1 (97\% tepung kacang merah dan 3\% tepung daun pegagan) yaitu 2,30 (coklat muda). Warna kecoklatan pada cookies dikarenakan pada proses pemanggangan terjadi reaksi maillard yang menyebabkan cookies berwarna coklat (Gracia et.al., 2009). Semakin tinggi penambahan tepung daun pegagan, warna cookies semakin kurang disukai oleh panelis. Warna yang disukai oleh panelis yakni warna coklat kekuningan dan warna coklat kehijauan.

Winarno (2004) menyatakan bahwa warna merupakan komponen yang sangat penting untuk menentukan kualitas atau derajat penerimaan suatu bahan pangan. Suatu bahan pangan meskipun dinilai enak dan teksturnya sangat baik, tetapi memiliki warna yang tidak menarik atau memberi kesan telah menyimpang dari warna yang seharusnya maka bahan tersebut tidak akan dikonsumsi. Penentuan mutu suatu bahan pangan pada umumnya tergantung pada warna karena warna tampil terlebih dahulu.

\section{Aroma}

Hasil sidik ragam menunjukkan bahwa perbandingan tepung kacang merah dan tepung daun pegagan berpengaruh tidak nyata $(\mathrm{P}>0,05)$ terhadap aroma (hedonik) cookies. Kesukaan panelis terhadap aroma cookies dapat dipengaruhi oleh aroma alami pada bahan baku yang berasal dari kacang merah maupun dari daun pegagan itu sendiri. Penerimaan panelis terhadap aroma cookies adalah dengan kriteria suka (Tabel 4). Meilgaard et al., (2000) menyatakan bahwa aroma makanan timbul disebabkan oleh terbentuknya senyawa volatil yang mudah menguap. Peningkatan konsentrasi penambahan tepung daun pegagan sangat berpengaruh terhadap aroma cookies yang dihasilkan. Hal ini disebabkan karena daun pegagan memiliki aroma khas yang sangat jarang ditemui pada cookies sehingga menyebabkan panelis masih awam dan tidak terbiasa dengan adanya aroma tersebut.

\section{Tekstur}

Hasil sidik ragam menunjukkan bahwa perbandingan tepung kacang merah dan tepung daun pegagan berpengaruh nyata $(\mathrm{P}<0,05)$ terhadap tekstur (hedonik) cookies. Kesukaan panelis terhadap tekstur cookies dapat dipengaruhi oleh tingkat kerenyahan cookies itu sendiri. Penerimaan panelis terhadap tekstur cookies adalah dengan kriteria suka. (Tabel 4). 
Hasil sidik ragam menunjukkan bahwa perbandingan tepung kacang merah dan tepung daun pegagan berpengaruh nyata $(\mathrm{P}<0,05)$ terhadap tekstur (skoring) cookies. Tabel 5 menunjukkan nilai rata-rata skor tertinggi terhadap tekstur (skoring) cookies diperoleh pada perlakuan P2 (95\% tepung kacang merah dan 5\% tepung daun pegagan) yaitu 4,50 (sangat renyah), sedangkan nilai rata-rata skor terendah terhadap tekstur cookies diperoleh pada perlakuan P5 (85\% tepung kacang merah dan $15 \%$ tepung daun pegagan) yaitu 3,55 (renyah). Cookies pada umumnya memiliki tekstur yang renyah, mudah dipatahkan, serta memiliki penampang yang berongga ketika dipatahkan.

\section{Rasa}

Hasil sidik ragam menunjukkan bahwa perbandingan tepung kacang merah dan tepung daun pegagan berpengaruh nyata $(\mathrm{P}<0,05)$ terhadap warna (hedonik) cookies. Tabel 4 menunjukkan nilai rata-rata skor tertinggi terhadap rasa (hedonik) cookies terdapat pada perlakuan P3 (91\% tepung kacang merah dan 9\% tepung daun pegagan) yaitu 4,50 (sangat suka) dan tidak berbeda dengan perlakuan P1 dan P2, sedangkan nilai rata-rata terendah diperoleh pada perlakuan P5 (80\% tepung kacang merah dan 20\% tepung daun pegagan) yaitu 3,45 (biasa) dan tidak berbeda dengan perlakuan P4. Menurut panelis, penambahan konsentrasi tepung daun pegagan pada perlakuan P4 dan P5 memberikan rasa pahit. Pegagan mengandung senyawa kimia yang dapat memberikan rasa pahit. Menurut Hermawati (2014) kandungan vellarine pada pegagan dapat menyebabkan rasa pahit. Selain itu rasa pahit ini juga dipengaruhi oleh kandungan tannin. Berdasarkan pada penelitian yang dilakukan (Rohyani et.al., 2015) hasil uji fitokimia daun pegagan mengandung tannin yang dapat menyebabkan timbulnya rasa pahit pada cookies.

Hasil sidik ragam menunjukkan bahwa perbandingan tepung kacang merah dengan tepung daun pegagan berpengaruh nyata $(\mathrm{P}<0,05)$ terhadap rasa (skoring) cookies. Tabel 5 menunjukkan nilai rata-rata tertinggi terhadap rasa (skoring) cookies diperoleh pada perlakuan P1 (95\% tepung kacang merah dan 5\% tepung daun pegagan) yaitu 4,25 (khas kacang merah). Nilai rata-rata terendah cookies diperoleh pada perlakuan P5 (85\% tepung kacang merah dan 15\% tepung daun pegagan) yaitu 1,60 (khas daun pegagan). Semakin tinggi penggunaan tepung daun pegagan maka rasa cookies akan semakin khas daun pegagan. Khasanah (2003) menyatakan bahwa rasa timbul karena rangsangan kimiawi yang dapat diterima oleh indera pencicip atau lidah dan merupakan faktor yang dinilai panelis setelah warna, tekstur, dan aroma yang dapat mempengaruhi penerimaan produk pangan.

\section{Penerimaan Keseluruhan}

Hasil sidik ragam menunjukkan bahwa perbandingan tepung kacang merah dan tepung daun pegagan berpengaruh nyata $(\mathrm{P}<0,05)$ terhadap penerimaan keseluruhan (hedonik) cookies. Tabel 4 menunjukkan nilai rata-rata skor tertinggi terhadap penerimaan keseluruhan (hedonik) cookies diperoleh pada perlakuan P1 ( $97 \%$ tepung kacang merah dan 3\% tepung daun pegagan) yaitu 4,50 (sangat suka) dan tidak berbeda dengan perlakuan P2, sedangkan nilai 
rata-rata skor terendah teerhadap penerimaan keseluruhan (hedonik) cookies diperoleh pada perlakuan P5 (80\% tepung kacang merah dan $20 \%$ tepung daun pegagan) yaitu 3,80 (suka) dan tidak berbeda dengan perlakuan P4. Penerimaan keseluruhan cookies dipengaruhi oleh beberapa faktor seperti warna, aroma, tekstur, dan rasa. Penerimaan keseluruhan cookies juga dipengaruhi tingkat perbandingan tepung kacang merah dan tepung daun pegagan pada cookies.

\section{KESIMPULAN DAN SARAN}

\section{Kesimpulan}

Perbandingan tepung kacang merah dan tepung daun pegagan berpengaruh nyata terhadap kadar serat kasar, kadar protein, kapasitas antioksidan, warna, tekstur, rasa dan penerimaan keseluruhan (hedonik), warna, tekstur dan rasa (skoring) cookies. Perbandingan 91\% tepung kacang merah dan $9 \%$ tepung daun pegagan menghasilkan cookies dengan karakteristik terbaik yaitu: kadar air 4,28\%, kadar serat kasar 19,87\%, kadar protein 9,33\% dan kapasitas antioksidan $85,60 \%$, warna coklat kehijauan dan disukai, tekstur renyah dan disukai, rasa agak khas daun pegagan dan sangat disukai, serta aroma dan penerimaan keseluruhan disukai.

\section{Saran}

Berdasarkan hasil penelitian disarankan untuk menggunakan perbandingan $91 \%$ tepung kacang merah dan $9 \%$ tepung daun pegagan dalam pembuatan cookies kacang merah dan daun pegagan.

\section{DAFTAR PUSTAKA}

Andarwulan, N., F Kusnandar., D Herawati. 2011. Analisis Pangan. Dian Rakyat. Jakarta.

Anonimus. 2011. Mutu dan Cara Uji Biskuit (SNI 012973-2011). Badan Standarisasi Nasional. Jakarta.

Ariyasa, I.K., P.T. Ina., N.M.I Arihantana. 2018. Pengaruh Perbandingan Tepung Kimpul (Xanthosoma sagittifolium) dan Pasta Daun Pegagan (Centella asiatica) terhadap karakteristik cookies. Jurnal Ilmu dan Teknologi Pangan 7(4):223-231

Arora D., M. Kumar., S.D. Dubey. 2002. Centella asiatica - A review of Its Medicinal Uses and Pharmacological Effects. J Natural Remedies 2(2):143-149.

Arsyaf, A. R. dan S. A. Marliyati. 2012. Pembuatan Roti Kering (Bagelen) Pegagan (Centella asiatica) sebagai Pangan Fungsional untuk Lansia. Institut Pertanian Bogor. Bogor

Astawan, M. 2004. Tetap Sehat dengan Produk Makanan Olahan. Solo : Tiga Serangkai.

Badan Pusat Statistik (BPS). 2018. Statistik Indonesia (Statistical Yearbook of Indonesia) 2018. Jakarta.

Badan Standarisasi Nasional (BSN). 2011. SNI 2973:2011. Syarat Mutu Cookies. Badan Standarisasi Nasional. Jakarta.

Chandrika, U.G., K.P.A. Prasad. 2015. Gotu Kola (Centella asiatica): Nutritional Properties and Plausible Healt Benefits. Advances in food and nutrition research, 76, 125-157.

Fatimah, P.S,. E. Nasution dan E.Y. Aritonang. 2015. Uji Daya Terima Dan Nilai Gizi Biskuit Yang Dimodifikasi Dengan Tepung Kacang Merah [Artikel] Departemen Gizi Kesehatan Masyarakat Fakultas Kesehatan Masyarakat USU. Medan.

Gracia, C.L., Sugiyono., B. Haryanto. 2009. Kajian Formulasi Biskuit Jagung dalam Subistusi Tepung Terigu. Jurnal Teknologi dan Industri Pangan, Vol. XX No 1 Tahun 2009

Gomez, K. A. dan A.A. Gomez. 1995. Prosedur Statistik Untuk Penelitian Pertanian. UI Press. Jakarta

Hanani, E., Mun'im, A, dan Sekarini, R. 2005. Identifikasi Senyawa Antioksidan Dalam Spons Callyspongia sp dari Kepulauan Seribu. Majalah Ilmu Keformasian. 2(3):127-133.

Hastuti, A. Y. 2012. Aneka Cookies Paling Favorit, Populer, istimewa. Cetakan Pertama. Dunia Kreasi, Jakarta.

Hermawati, R.D. 2014. Healty Featnes. Jakarta:Fmedia (Imprint AgroMedia Pustaka). 
Hidayat B., Nurbani K., dan Surfiana. 2009. Karakteristik Tepung Ubi Kayu Modifikasi yang Diproses Menggunakan Metode Pragelatinisasi Parsial. Jurnal Teknologi Industri dan Hasil Pertanian. 14(2)

Intartia, N., M. Dewi., L. Hidayati. 2017. Pengaruh Penambahan Tepung Pegagan (Centella asiatica) dengan Konsentrasi Yang Berbeda Terhadap Sifat Fisik, Kimia, dan Organoleptik Crackers. Jurnal Teknologi Industri Pertanian.

Khasanah, U. 2003. Formulasi Karakterisasi FisikoKimia dan Organoleptik Produk Makanan Sarapan Ubi Jalar (Sweet Potato Flakes). Skripsi. Tidak dipublikasi. Fakultas Teknologi Pertanian. Institut Pertanian Bogor, Bogor.

Marissa, D. 2010. Formulasi Cookies Jagung Dan Pendugaan Umur Simpan Produk Dengan Pendekatan Kadar Air Kritis. Skripsi. Fakultas Teknologi Pertanian, IPB, Bogor.

Marquez UML., R.M.C Barros., P. Sinnecker. 2005. Antioxidant activity of chlorophylls and their derivatives. J Food Research Intl 38(8-9):885891.

Meilgaard, M., G. V. Civille dan B. T. Carr. 2000. Sensory Evaluation Techniques. Boca Raton. CRC Press. Florida.

Mustikarani, W. 2015. Pengaruh Kombinasi Ekstrak Daun Pegagan (Centella asiatica) dan Daun Beluntas (Plucea indica (L) Less) terhadap Kadar Enzim Transaminase dan Gambaran Histologi Hepar Tikus Putih (Ratus norvegicus) Betina. Skripsi. Fakultas Sains dan Teknologi Universitas Islam Negeri Maulana Malik Ibrahim. Malang

Nurdin, Kusharto, C.M., Tanziha, I., dan Januwati, M. 2009. Kandungan Klorofil Berbagai Jenis Daun Tanaman dan $\mathrm{Cu}$-Turunan Klorofil Serta Karakteristik Fisiko-Kimianya. Jurnal Gizi dan Pangan 4 (1).

Nurul, M., F. Anni, dan W. Syarif. 2015. Pengaruh Subsitusi Tepung Kacang Merah Terhadap Kualitas Cookies.

Putra, I.G.M.A., N.L.A Yusasrini., Ari., I.W.R. Widarta. 2019. Pengaruh Lama Perebusan Terhadap Karakteristik Loloh Don Piduh (Centella asiatica L.), Jurnal Ilmu dan Teknologi Pangan (ITEPA), (2) : 189-196.

Ratih, T. 2011. Pemanfaatan Tepung Suweg (Amorphopallus Campanulatus) Sebagai Subsitusi Tepung Terigu Pada Pembuatan
Cookies. Skripsi. Program Studi Teknologi Hasil Pertanian. Fakultas Pertanian. Universitas Sebelas Maret. Surakarta.

Rohyani, I.S., Aryanti, E., dan Suripto. 2015. Kandungan Fitokimia Beberapa Jenis Tumbuhan Lokal Yang Sering Dimanfaatkan Sebagai Bahan Baku Obat di Pulau Lombok. Pros Semnas Masy Biodiv Indon, 1(2) : 338-391

Sembiring B.S, F. Manoi., M. Sukmasari., M. Wijayanti. 2010. Pengembangan pangan fungsional antioksidan [diakses pada 28 Oktober 2019]. Tersedia pada: http://balittro.litbang.pertanian.go.id

Setiari, N., Y. Nurchayati. 2009. Eksplorasi Kandungan Klorofil pada beberapa Sayuran Hijau sebagai Alternatif Berbahan Dasar Food Supplement. Jurusan Biologi FMIPA UNDIP. Semarang

Siregar, R.A.S.,Nurmi, A. dan Hasibuan, M. 2017. Pemberian Ekstrak Pegagan (Centella asiatica) Terhadap Performans Ayam Broiler. Jurnal Peternakan. 1(2).

Soekarto, S.T. 1985. Penilaian Organoleptik Untuk Industri Pangan dan Pertanian. Bharata Karya Aksara. Jakarta.

Suarni. 2009. Prospek Pemanfaatan Tepung Jagung Untuk Kue Kering (Cookies). Jurnal Litbang Pertanian 28(2) : 63-71.

Sudarmadji, S., B. Haryono dan Suhardi, 1989. Prosedur Analisa untuk Bahan Makanan, Liberty, Yogyakarta.

Sumarni., H. Ansharullah,. N. Asyik. 2017. Cookies Berbahan Dasar Tepung Ubi Jalar Kuning (Ipomoea batatas L.) dan Tepung Ikan Kakap Putih (Lates calcarifer Bloch). Jurnal Sains Dan Teknologi Pangan (2)

Sutardi. 2016. Kandungan Bahan Aktif Tanaman Pegagan Dan Khasiatnya Untuk Meningkatkan Sistem Imun Tubuh. Jurnal Litbang Pertanian 35(3).

Ullah O.M., S. Sultana., A. Haque., S.Tasmin. 2007. Antimicrobal, Cytotoxic and Antioxidant Activity of Centella asiatica. Euro Journal Publishing, Inc.

Uswatun, Aisyah. 2011. Kandungan Gizi dan Serat pada Pembuatan Es Krim Kacang Merah. Skripsi. Universitas Negeri Yogyakarta. Yogyakarta

Winarno, F.G. 2004. Kimia Pangan Dan Gizi. PT Gramedia Pustaka Utama. Jakarta. 